\title{
The sharing economy: the emerging debate in Spain
}

\author{
Borja SuÁrez Corujo \\ Profesor Titular de Derecho del Trabajo y Seguridad Social \\ Universidad Autónoma de Madrid
}

Recibido: 14.05 .2017

Aceptado: 13.06 .2017

https://doi.org/10.20318/sllerj.2017.3923

\begin{abstract}
Focusing attention on work-on-demand via apps, this article deals with the consequences of the slow emergence of the so-called sharing economy in Spain. As far as the labour field is concerned, it examines the advantages and risks that this new type of service provision (work?) entails and how Spanish law treats it as a previous step to reflect on the ability of the (labour) current regulation to secure 'collaborators' decent working conditions. By extension, it also analyzes the impact that these developing activities could have on the Social Security system, in terms of protection (or lack of it) and financial condition.
\end{abstract}

Keywords: sharing economy, employee, employmen contract, social security.

\section{Introduction}

Whether we are or not living what has been called the fourth industrial revolution ${ }^{1}$, the economy is going through a process of great technology-driven transformation which is changing the nature of employment in very different ways. One of them concerns the rise of economic activities which are based on the use of on-line platforms. Major questions are immediately raised, the most relevant one being whether the task/service provided must be considered work or not from a legal perspective. In-depth considerations are to be made throughout the paper.

At this point my attention is drawn to the evidence that this 'platform work' certainly has similarities with other forms of nonstandard employment. But is it a specific (autonomous) category or is it nonstandard employment itself? Moreover, and if we admit the latter, for how long will this type of work maintain this status given the rapid development of these new forms of economic activity? Focusing on the conditions in which such tasks/services are carried out, serious doubts rise regarding risks of precariousness, casualization and commodification of work, and the emergence of 'invisible' workers. Such circumstances become real obstacles to guaranteeing decent work.

On the whole, what is at stake is the future of work and its implications in very different fields that the law tries to command. In this regard, labour law is facing a major challenge: how to preserve the traditional guarantees which have historically balanced the relationship between labour and capital

${ }^{1}$ Borrowing the expression used by SCHWAB (2016). 
in western Welfare States. By extension, this deep transformation threatens the current design of those Social Security systems, such as the Spanish one, where benefits are primarily based on the previous contributions made by workers.

\section{Shaping the concept of 'sharing economy'}

The almost brand-new expression 'sharing economy' or 'collaborative economy' (economía colaborativa in Spanish) is often overused. Increasingly the type of activities developed has little to do with real sharing, lying closer to simple selling and profit seeking ${ }^{2}$. In that respect it is probably a misleading concept ${ }^{3}$ that should be replaced by a more generic expression. Such alternative formulas are already common in English: gig economy, digital on-demand economy, platform economy... On the contrary, scholars and experts are finding more difficulties in Spain to coin an accurate term that includes a wide range of activities, described by the European Commission as ".. business models where activities are facilitated by collaborative platforms that create an open marketplace for the temporary usage of goods or services often provided by private individuals"4. In an attempt at clarification that sheds light over this diversity, we suggest making a triple-fold distinction.

First of all, one category could be what we may identify as sharing economy in a strict sense. This is a type of economic activity where a collaborative component is openly present. Often linked to consumption, two basic features may be pointed out. One is that providers act as private individuals, not professionals, so that we come across a new character: 'prosumer', a hybrid resulting from producer and consumer. And another would be that these activities are not for profit or, at least, that they are inspired by the principles of social economy.

The suggested taxonomy would include as a second category the crowd-work or crowd-sourcing online. It refers to those working activities that imply completing tasks (often 'microtasks') characterized as follows: first, they are offered on a competitive base to a large number of people (crowd) through online platforms; and second, they are paid to the crowd-worker either by the 'client' (crowd-sourcer) or by the platform itself depending on the role of the platform in contractual terms. Certain parallelism with home-work can be found in this case 5 .

Finally, there is still a third category, partially similar to the former, named as work-on-demand via apps, where the execution of traditional or (increasingly more frequent) non-traditional working activities is characterized in the following terms. It shares with crowd-sourcing online three key aspects: one, it is based on just-in time relationship where the 'collaborator' is in theory free to determine his/ her time availability; two, it is channeled through apps which are managed by firms that set minimum quality standards in the service provider and manage the 'workforce' with more or less strict criteria; and three, the performance is compensated on a 'pay-as-you-go' basis. Beyond these features, the key difference is that tasks are physically delivered (crowdsourcing offline), which in principle limits the number of potential collaborators.

My attention in this article will focus on this last category for three main reasons. On the one hand, work-on-demand via apps is to be considered the most common of the new (digital) forms of work that are developing in Spain. On the other, given its offline component this type of 'work' seems to be closest to the 'typical' (traditional) employment relationship. And finally, it is consistent with a consolidated line in the labour field which seeks cost reduction and profit maximization by adding (extreme) flexibility in a context of high competitiveness.

\footnotetext{
${ }^{2}$ As ALOISI $(2016,664)$ points out, often “... 'sharing' could be seen as a euphemism for 'selling'...”.

${ }^{3}$ DRAHOKOUPIL-FABO $(2016,1)$.

${ }^{4}$ Communication from the Commission to the European Parliament, the Council, the European Economic and Social Committee and the Committee and the Committee of the Regions, "A European agenda for the collaborative economy", Brussels, 2.6.2016, $\operatorname{COM}(2016) 356$ final.

${ }^{5}$ RISAK and WARTER (2015) defend such a remark arguing that it could even fall into the definition of the ILO Home Work Convention (No. 177).
} 


\section{The debate on 'sharing economy': Why is it emerging so slowly in Spain?}

The debate on 'sharing economy' has only very recently started in Spain and it has not drawn too much attention so far. It reflects a (relatively) low development of these new business models in this country caused by certain factors regarding the current legal and socioeconomic circumstances.

Firstly, there are specific characteristics of the Spanish economy which constrain the interest for this type of on-demand activities. One of the consequences of the rising digitalization of the economy is the polarization of the employment ${ }^{6}$ : the amount of high-skilled and low-skilled employees grows as the intermediate-skilled ones, often linked to 'classic' industrial activities, lose their jobs due to the technological transformation and the concurrent process of tertiarization of the economy. However the fact that the Spanish economy is characterized by the importance of a tertian sector that intensively uses (an excessive number of) workers with low skills implies that the potential for further polarization of the employment is limited. In a way it could be stated that such a polarized economy already exists in Spain.

Secondly, it is evident that the context of economic crisis and austerity-driven policy has had a negative impact on the development of these new business models. From mid-2008 until the beginning of 2014 more than 3.6 million jobs were lost as a result of a double-dip recession, so that economic growth has only taken place since 2015. That is to say that the moment the gig economy takes off in other countries (around 2010) there were no favourable conditions in Spain. Here it is still a fairly new phenomenon.

Thirdly, it must be taken into account that the (ultra)flexibility sought by the new 'gig economy' is ordinarily reached in Spain through alternative channels favoured or spoiled by the labour regulation. Although a widespread idea claims that the Spanish labour market is very rigid, its real functioning shows a great deal of flexibility that causes severe instability by means of the following factors. One, an excessive level of temporary employment that very often is not based on temporary reasons as the regulation formally requires. Two, the overuse of dismissals as an instrument to adjust production, avoiding other measures of internal flexibility much more effective in maintaining employment and lowering adjustment costs in a context of economic contraction ${ }^{7}$. And three, other anomalous practices that aggravate precariousness such as a very high proportion of involuntary part-time work, and intense job rotation.

Lastly, there have also been occasional, but real, legal obstacles to the development and expansion of these new platform activities. On the one hand, Competition Law has deterred the development of new businesses in regulated sectors; Uber's case is the best example ${ }^{8}$. On the other hand, we might also consider that Labour Law could have in a way restrained the flourishing of 'gig economy' as a consequence of the actions (or threat of actions) taken by the Inspectorate of Labour and Social Security whereby the so-called 'collaborators' (acting as independent contractors) were classified as workers with the subsequent legal consequences: labour guarantees and Social Security obligations for the employer?.

All in all, the aforementioned circumstances decisively contribute to the (relatively) slow growth of 'gig economy' in Spain. And this probably explains the scarce attention paid to this new phenomenon by the Spanish labour law scholars so far despite the very serious implications that it has for labour and Social Security regulation ${ }^{10}$.

\footnotetext{
${ }^{6}$ AUTOR (2014).

${ }^{7}$ A widespread idea traditionally claims that the Spanish labour market is rigid mainly because it is difficult and/or expensive to dismiss permanent workers. Quite the opposite, OECD Indicators of Employment Protection shows that such a conclusion has never been accurate, even less after the 2012 labour market reform. See: SUÁREZ CORUJO (2014, 57).

${ }^{8}$ Among other legal actions, a licensed taxi-drivers association in Barcelona claimed that Uber was providing a transportation service breaching the Spanish unfair competition law. A commercial court made in 2015 a make a reference to the Court of Justice for a preliminary ruling on the nature of Uber's activity (transport service or an information society service). The judgement is still pending.

${ }^{9}$ As a matter of fact, in the EsLife case the startup decided to close down the activity after the Inspectorate of Labour declared that its 'collaborators' providing cleaning services merited the condition of workers.

${ }^{10}$ As salient exceptions, see: SIERRA BENITEZ (2015); GINÉS i FABRELLAS - GALVEZ DURAN (2016); CAVAS MARTÍNEZ (2017); TODOLÍ SIGNES (2017).
} 


\section{4. 'Sharing' economy and its impact seen from the spanish perspective}

The main contribution of this article deals with the responses given by Spanish law in two different, although closely linked, fields: Labour Law and Social Security Law. It is to be noted at this point that although most of the analysis carried out by experts have concentrated on the labour issues, those regarding the Social Security system are equally relevant and therefore should not be forgotten.

\section{A. Employment relationship}

This section tackles two central questions regarding the development of these new forms of work on-demand via apps in Spain. One wonders how Spanish (Labour) Law treats this type of work; in other words, does it fall into the field of Labour Law or is the nature of the relationship that supports the activity different? Likewise, once the position within the legal frame is determined, a second question is pertinent: has the current regulation the ability to secure decent working conditions?

As a preliminary consideration, it is undeniable that this new phenomenon that could be named 'uberization' of the economy will (potentially) have significant implications for the labour market and its regulation. Focusing the attention on the collaborators' side, there are certainly (potential) positive effects stemming from participation in these types of (economic) activities.

In this regard, the main advantage has to do with the flexibility that it offers to workers ('collaborators'). In principle, this is always attractive as a way of having full control of time. But it is especially relevant in those cases where carrying out this monetary activity must be compatible with other such as care responsibilities, education, etc. Thus it could favour an extension of the labour force benefiting youth and women, among others ${ }^{11}$. Furthermore work on-demand via apps (certainly more crow-sourcing on line) could increase as well the employment opportunities for job seekers with special difficulties (disability, health problems...) and limited capacity of movement.

'Uber-like' activities are also attractive as a convenient way of earning additional income when the 'collaborator' has a regular job. Or it makes it easier to combine 'working' for different platforms which in certain cases could be interesting in order to reduce the dependence on a single one and to maximize the profit obtained with respect to the time invested.

Finally, the growth of this platform activity could contribute to reducing the size of undeclared economy. The thorough digitalization of an activity that directly affects three different parties favours control and makes illegal practices more difficult. And this would be particularly relevant in a country such as Spain where tax fraud is extensive.

Having said this, many voices have warned against the negative effects that this process of uberization of the economy could have. Those inconveniences are mainly associated with distinctive drivers of these types of activities. One is an excess of labour flexibility: although such flexibility may in principle equally benefit both parties, the experience shows that it generally tips the balance in favour of platforms ${ }^{12}$; that is to say that it is a kind of flexibility that does not entail a greater freedom for the worker ${ }^{13}$. Another one is individualization in a two-fold sense: on the one hand, the collective dimension is annulled, as we will see; and on the other, a key element in reducing labour costs lies in the fierce competence among 'collaborators'. And finally, the third driver refers to the blurring role played by online platforms, very often deliberately sought.

In an effort to be more precise, 'collaborators' might be exposed to various labour risks which weaken their contractual position with respect to negotiation and the actual conditions of performance. Such risks are to be classified into three main groups.

Given that these types of activities are often carried out on a just-in-time, intermittent or irregular basis, the first group includes risks associated with key professional conditions. One is that short-time

\footnotetext{
${ }^{11}$ DE GROEN - MASELLI $(2016,24)$.

${ }^{12}$ As PRASSL and RISAK $(2016,624)$ observe, this “... increasing desire for labor flexibility...” has been the driver behind the emergence of different forms of atypical work.

${ }^{13}$ ALOISI $(2016,662)$.
} 
activities could jeopardize a sufficient level of income. That would not be a major problem in those cases where work on-demand via apps does not account for the main source of earnings, but it is an actual threat of underpayment if it is the principal activity. Note that this could be circumventing or eluding minimum wage regulation: on the one hand, it does it directly when the 'collaborator' acts as an independent contractor as there is no bottom limit for payment; and on the other, microtasks and just-in-time services increase the risk of low-wage workers ${ }^{14}$ opening the door to in-work poverty and economic instability.

And from a different perspective, another risk has to do with working time given the fact that the 'collaborator' is (theoretically) free to determine when to be 'active'. In particular, as the payment for the service may not be generous, overworking could be a reality and, in that sense, a way of selfexploiting in order to guarantee a decent level of income ${ }^{15}$.

A second group of risks reflect that the reinforcement of the platform's position within the contractual relationship goes too far even in terms of labour regulation where a strong subordination is characteristic. Alongside thorough supervision and strict control on the service carried out, the relevance given to the client's ratings cause great vulnerability to 'collaborators'. Especially when we take into account that, as a general rule, platforms have the power of (account) 'deactivation' -a denial of the opportunity to offer services through the app. It is evident that this is to be deemed a sort of disciplinary power that attempts to legitimize what probably constitutes an abusive way of contractual termination which seriously threatens all different dimensions of stability.

Finally, risks also stem from the strong individualistic component of the service provision that virtually annuls the collective dimension of an activity carried out by an undefined (usually numerous) group of 'collaborators'. This means that the individual vulnerability already described cannot be faced by the typical collective subjects and actions of Labour Law. To be more precise, it is not that collective action is not possible: as the Uber cases in the US and the $\mathrm{UK}^{16}$ prove, there is a certain margin for it despite the initial attempt at leaving aside labour regulation. But we have to be conscious that channeling the contractual relationship outside the labour field entails that the legal means to defend common interests to the 'collaborators' are very limited. And, thus, it aggravates the weaknesses associated with their 'invisibility' and the existence of huge competition among them.

On the whole, we can state that the development of these work on-demand via apps directly cause great uncertainty to 'collaborators'. This normally turns into acute instability and precarious working conditions which, if no specific response is given, could foreseeably lead to the emergence of a new group of precariat ${ }^{17}$. In this respect, the legal classification of the relationship between the online platform and the service provider is a key issue, given the fact that independent contractors do not enjoy any labour guarantees. However, we should be note that probably neither of the regulations applied (including labour legislation) offers an adequate response to the challenges that the uberization of economy brings about.

\section{a) Legal classification of the relationship between on-line platform and service provider}

There are three possible classifications in Spanish Law according to the specific characteristics of the relationship between the platform and the 'collaborator', not to the name given by the parties, as we will see.

First of all, the one used in practice so far is to identify them as independent contractors, that is to say self-employed who are in business on their own account. This implies the absence of any specific guarantees beyond the basic ones recognized by common private law between parties or contained in the Self-Employed Workers' Statute (Act 20/2007).

\footnotetext{
${ }^{14}$ DAGNINO $(2015,10)$.

${ }^{15}$ In crowd-sourcing online there is also a risk linked to the cost of time searching for microtask that are very low paid.

${ }^{16}$ Mr. Y. Aslam, Mr. J. Farrar and Others v. Uber (https://www.judiciary.gov.uk/judgments/mr-y-aslam-mr-j-farrar-andothers-v-uber/ ).

${ }^{17}$ See: STANDING $(2014,224)$.
} 
Secondly, service-providers could be classified as economically-dependent self-employed workers [trabajadores autónomos económicamente dependientes, TRADEs]. By virtue of section 11 SelfEmployed Workers' Statute, this category refers to those who usually, personally and directly carry out an economic or professional activity for income purposes receiving $75 \%$ (or more) of their income from one single client. Even though the analysis of this peculiar type of self-employed is not one of the purposes of this article ${ }^{18}$, it is nevertheless important to underline two aspects with respect to its legal regulation. On the one hand, certain guarantees are (partly) secured by the law regarding conditions on contract termination, working time limitations, coverage against work-related accidents and cessation of activities, and the recognition of collective agreements. On the other, a further requirement to obtain the status as economically-dependent self-employed workers is a formal recognition by the client (section 11 bis Act 20/2007), a major obstacle in practice as we will see infra.

Lastly, the third possible classification is that of employees. According to section 1 of Workers' Statute (Royal Legislative-decree 2/2015), they are defined as those rendering services for another person within the scope of the organization and management of that person, the employer. Needless to say, such a condition opens the door to all labour guarantees for employees and the correspondent obligations for employers.

There are still two additional and closely-related remarks to be made regarding this triple-fold classification. One is that section 8 of the Workers' Statute contains a 'labour presumption': a contractual relationship whereby someone personally works for the benefit and under the direction of someone else in exchange of remuneration is, in principle, considered as an employment contract ${ }^{19}$; so unless it is proven that one or more of those defining characteristics are not present in certain cases, the appearance leads to the recognition of labour status. This also implies, as a second remark, that in Spanish Law contractual classification is not dispositive. That is to say that a "primacy of fact" principle rules, in the sense that it is facts, and not labels, which determines the attribution of employee status or, on the contrary, the existence of a commercial relationship ${ }^{20}$.

In conclusion, legal classification will depend on the result of a multifactorial test that will be based on the facts emerging from the relationship between the platform and the service provider ('collaborator') ${ }^{21}$. Specifically, attention should be drawn to those defining features that separate the concepts of employee and self-employee in Spanish Law (section $1 \mathrm{WS}$ ), which are questioned in these types of cases. So we are back facing what has been expressly described as the 'cornerstone' of Labour and Employment Law ${ }^{22}$.

Leaving aside two of the defining characteristics of the employee (personal work and remuneration), I will focus on the ownership of the benefit and, above all, the (lack of) subordination with respect to the potential employer. As far as the former is concerned, we could probably state that, notwithstanding being a highly casuistic issue, it will remain (it certainly does, so far) largely unchallenged since the 'collaborator' works for a platform (to the platform's benefit) pursuant to a contract. So the claim that platforms act as technological companies ${ }^{23}$ whose activity is limited to matching demand and supply cannot be accepted for two main reasons. One, because the business is not viable without the participation of 'collaborators'. And, two, for it tends to be evident that the platform does not sell software, but services that are provided by 'collaborators' usually subject to detailed instructions.

The key aspect is whether the service is provided by the 'collaborator' in a dependent or independent manner with respect to the platform: in the first case, that will reflect the subordination that

\footnotetext{
${ }^{18}$ Extensively on this issue: PÉREZ REY, J. (2016).

${ }^{19}$ Note that such a provision is in line with ILO Recommendation No. 198 that encourages to provide for “... a legal presumption that an employment relationship exists where one or more relevant indicators is present".

${ }^{20}$ See, as an illustration of this principle, the Spanish Supreme Court (Social Chamber) Ruling of 25 January 2000 (No. $582 / 1999)$.

${ }^{21}$ ALOISI $(2016,669)$.

${ }^{22}$ See DAVIDOV $(2002,358)$, quoting the renowned work by KAHN-FREUND (1956) [“Legal framework”, in: FLANDERS, H. - CLEGG, H.A. The system of industrial relations in Great Britain: Its History, Law and Institutions, Basil Blackwell, Oxford, 1956, pp. 42-45].

${ }^{23}$ See the request for a ECJ's preliminary ruling from the Juzgado Mercantil No. 3 de Barcelona (Spain) lodged on 7 August 2015 - Asociación Profesional Élite Taxi v Uber Systems Spain, S.L. (Case C-434/15).
} 
characterizes an employment relationship; while in the second one, such autonomy would lead us to classify the provider as an independent contractor.

Following Spanish case-law ${ }^{24}$, the assessment of (in)dependency in case of uber-type collaboration should be based on the already mentioned multiple test that takes into account signs of the existence or not of such a feature. From a general point of view, a traditional analysis of the potential employee status would find strong evidence of independency (self-employment) stemming from the following contractual conditions ${ }^{25}$. First, the most relevant one arguably is that working time is determined at the collaborator's discretion, which means that there is no fixed timetable and, even more importantly, that the very 'collaborator' decides when to be active in the platform. Second, and along the same lines, it is common that he/she enjoys freedom to refuse tasks commanded through the platform. Third, it seems to show autonomy that the performance of the activity is basically self-directed, notwithstanding the existence common instructions directed to all 'collaborators'. Fourth, the nonexclusivity of the contractual engagement, that is to say, the possibility of 'collaborating' with several platforms is generally considered a sign of independence (ancillary income). And, fifth, the fact that activity-related spending is not compensated for by the platform could also indicate that the service is provided on his/her own account.

Having said that, evidence of dependency of the 'collaborator' on the platform are also frequently found in practice, some of them being typical signs of a traditional idea of subordination and some others showing new forms of such dependency. Firstly, in cases of work-on-demand via apps, where the performance is physically carried out, it is common to have 'collaborators' fulfill certain conditions before being activated. Secondly, another sign of subordination lies in the personal dimension of the performance in the sense that it is not transferable. Thirdly, according to the experiences analyzed in Spain, the supremacy of platforms is obvious in very different aspects: strict (no matter if indirect) supervision and control; detailed indications of how to perform the tasks; three, price fixing of services performed; sham incentives on 'activation' that hide a minimum level of availability. Fourthly, the fact that the platform is allowed to 'deactivate' 'collaborators' in a wide range of circumstances shows a sort of disciplinary power, one of the most typical characteristic of employers. And fifthly, without being exhaustive, it is also a sign of subordination of 'collaborators' that the relationship established with the client (payment included) is always channeled through the platform.

So far, contracts signed by web-based platforms and service providers usually classify the latter as independent contractors (self-employed). Only exceptionally -in one case due to an intervention of the Labour Inspectorate ${ }^{26}$-, service providers are considered as employees carrying out a service under a contract of employment signed with a platform who acts as employer. Is this interpretation moving away from Labour Law reasonable?

It is certainly risky to make a general judgement on such a casuistic issue. But what concrete experience shows in very recent years in Spain is that one of the main points sought by this new kind of business model is to reduce 'labour' costs. So it could be stated that, deliberately or not, considering 'collaborators' as independent contractors tries to circumvent labour and Social Security regulation. In other words, in most cases we would be in front of bogus self-employed that shows that the aim pursued is not only reducing (or eliminating) the cost of unproductive time at work ${ }^{27}$, but often to avoid the constraints of Labour Law.

Then the question to be posed is what would be the adequate legal classification of this type of contractual relationship. Apparently classification as economically-dependent self-employed workers (TRADEs) could be reasonable as an intermediate category that reflects the mix of features that makes it difficult to give a clear-cut response according to the traditional patterns. Note that this solution might be

\footnotetext{
${ }^{24}$ See: CRUZ VILLALÓN (1999).

${ }^{25}$ See a complete analysis of this issue in MERCADER $(2017,90)$.

${ }^{26}$ In the EsLife case, a startup providing home cleaning services that decided that decided to quit its activity after an intervention by the Labour Inspectorate whereby 'doers' (terminology used by the company to refer to cleaners) were to be considered employees, not self-employed workers. The corresponding obligations, namely Social Security contributions, brought along an important cost increase that the company could not afford according to its representatives.

${ }^{27}$ PRASSL and RISAK $(2016,625)$.
} 
attractive for both parties as it offers a minimum level of professional guarantees to 'collaborators', and flexibility and reduced costs to those firms behind the platforms. However, it does not seem to be a real option. Besides the (more theoretical?) objection that 'collaborators' may diversify their activity among different platforms not fulfilling the legal requirement of rendering services principally $(75 \%$ of their income) for one client, current regulation presents a significant obstacle ${ }^{28}$ : the requirement of a formal recognition of TRADE's status (or the way it is foreseen by the Law) is preventing this potential group from growing ${ }^{29}$. Therefore, notwithstanding that such a condition can be successfully claimed in court, the reality is that the number of registered economically-dependent self-employed workers has always remained very $\operatorname{low}^{30}$, even after a legal amendment in 2011.

Having verified that the legal classification as economically-dependent self-employed does not seem to be an effective response to the challenge set by work-on-demand via apps, it is reasonable, in principle, to conclude that an employment relationship exists according to the case law ${ }^{31}$. But various questions immediately arise revealing what arguably can be considered an unsatisfactory regulation.

Doubts arise concerning the type of employment contract in terms of duration. Given the just-in time performance characteristic of the 'uberized' activities and the overuse of temporary work in the Spanish labour market, it easy to imagine the temptation to channel the relationship through a fixed-term contract. Nevertheless, as service provision (through the app) constitutes the main activity regularly carried out by the platform, we are bound to conclude that the appropriate type of contract is one of indefinite duration. But therefore we have to face new legal problems.

In particular, the peculiar working time characteristic of this type of activity would normally lead us to conclude that 'collaborators' are deemed to be part-time employees. However, another feature forces an additional remark. We are referring to the fact that the service/task is provided on an irregular or intermittent basis. That means that, in principle, this employment relationship would fall outside the scope of part-time contracts ${ }^{32}$ and consequently correspond to a fixed discontinuous one. Once again such a solution raises doubts that reflect the inadequacy of current regulation on this contractual relationship. Just as an illustration, we could ask ourselves whether the requirement of 'homogeneous activity' is fulfilled ${ }^{33}$ or how the right to be called to work is exercised.

\section{b) Beyond legal classification: the vulnerable position of platform 'collaborators'}

Beyond the legal classification of uber-like 'collaborators', we may conclude that their position is very vulnerable in any of the three cases mentioned, employment relationship included. So it appears to be necessary to reconsider certain legal aspects as a way of guaranteeing decent working conditions.

We have already seen that 'collaborators' are normally classified as self-employed workers. Leaving aside dubious practices seeking to avoid labour regulation, in most cases the specific characteristics of the contractual relationship may well support a different classification according to Spanish Law. The first alternative -economically-dependent self-employed workers- does not seem to be fully satisfactory. On the one hand, given the poor numbers registered so far, a legal amendment making it easier to attribute is indispensable. And even if we overcome this obstacle it is not clear, on the other hand, that

\footnotetext{
${ }^{28}$ See: AGUT GARCÍA y NÚÑEZ GONZÁLEZ $(2012,130)$.

${ }^{29}$ On the requirement of communication to the client as a constituent element, see GINÉS i FABRELLAS and GALVEZ DURAN $(2016,14)$.

${ }^{30}$ The specific Register for economically-dependent self-employed workers at the Public State Employment Service, which belongs to the Ministry of Employment and Social Security, merely counts 16.000 TRADEs. A high contrast in comparison to the circa 260,000 self-employed working for one single client estimated by the National Statistics Institute in the Economically Active Population Survey.

${ }^{31}$ It is interesting in comparative terms to recall the main functions underpinning the position of employer according to PRASSL and RISAK (2016, 636): inception and termination of the employment relationship; receiving labor and its fruits; providing work and pay; managing the Enterprise -internal market; managing the Enterprise - external market.

${ }^{32}$ This would include fraudulent part-time work on demand, as well as sham private employment agencies (DE STEFANO 2016,9).

${ }^{33}$ Vid. Supreme Court ruling of 24 February 2016, among others.
} 
the solution will be adequate since this intermediate category could be used to cover real employment relationships according to section of the Workers' Statute ${ }^{34}$.

So focusing on the labour field, we must be conscious of the difficulties and limitations shown by the current legal framework originally conceived to give responses to a very different economic environment. This means that, in order to prevent a significant escape of individuals from the scope of Labour Law, the definition of employment relationship has to be adapted and reinforced in a two-fold manner.

First of all, a key aspect is the redefinition of the concept of 'dependence' on the employer as one of the defining features of an employee. The traditional idea of rendering services within the scope of the organization and management of the employer gives way in a digital economy to a new characterization. Among other changes, it is noteworthy that, rather than strict subordination, the employment relationship is mainly defined by the existence of economic dependence. Along these lines, monitoring is performed in a very different manner: although there is no physical presence, employer's control can be equally, or even more, effective thanks to new instruments such as client's rating and its impact on digital reputation ${ }^{35}$. From a different perspective, the very position of employer could be in certain cases altered: it is relatively common for start-ups to have a business model based on no big investments that are exposed to a higher risk of failing. In that sense, it is not exaggerated to speak of more prevalent business 'precariousness', a relevant factor that tends to aggravate the employee's dependence.

Secondly, and as a logical step forward, it urges to adapt labour regulation and institutions to the new working forms, so that the resulting legal framework offers sufficient flexibility to platforms, while preserving at the same time labour guarantees in favour of 'collaborators'. The question is how to achieve such an ambitious goal.

De lege ferenda, two main solutions are conceivable. TODOLI has suggested that the most appropriate option would be the formulation of a new special employment relationship. This means that, without being excluded from Labour Law, the aforementioned contractual relationship would be subject to a specific regulation purposely designed to reflect the singularity of certain circumstances typical of the new economic activities ${ }^{36}$. However, there are two objections to be made. On the one hand, it is foreseeable that an ad hoc regulation would imply -following most of the special employment relationships- certain sacrifices for employees in favour of employer interests. And, on the other, in the long (possibly even medium) term this new sort of business model will probably represent a major proportion of economic activity, not a minor part as it does today. Therefore a special regulation could turn to be a way of undermining labour rights.

In my opinion, it is more reasonable to classify platform 'collaborators' as ordinary employees. That is compatible with adapting the Workers' Statute to the singular working conditions, which characterize this type of activity, by following the example of the current remote working clause (section $13 \mathrm{WS}$ ): a new section regulating its singularities (working time, salary, surveillance, etc.), within the general legal framework applied to common employment relationships.

\section{B. Social security}

Difficulties of formal classification in legal terms, as well as the specific characteristics of work on-demand via apps create problems from the perspective of Social Security. In brief, questions such as the following arise: how does the Spanish system of Social Security treat these new forms of work?; has it the ability to secure adequate social protection?; and, from a broader point of view, could the gig economy impact on the financing of Social Security and its future sustainability?

Focusing on the formal side of the relationship, the first issue to deal with is determining which scheme, if any, corresponds when registering with the Social Security system. The answer basically stems from the contractual classification. That is to say that when the platform 'collaborator' has the

\footnotetext{
${ }^{34}$ This skeptical view on intermediate category is shared by DE STEFANO $(2016,20)$ with respect to Italy.

${ }^{35}$ PRASSL and RISAK $(2016,625)$.

${ }^{36}$ See: TODOLI SIGNES, A. $(2015,17)$. More extensively by the same author: TODOLI SIGNES, A. $(2017,71-75)$.
} 
condition of employee he/she will be bound to register with the General Scheme, whereas independent contractors (including economically-dependent self-employed workers) enroll in the Special Scheme for Self-Employed Workers.

However, the fact that the services performed are often sporadic complicates the answer. At this point, a distinction must be made between those cases where 'collaborators' act as independent contractors and those others in which, despite being occasional services/tasks, the defining features of the concept of employee are met. With respect to the latter, the rule is that all employment relationships require registration with the General Scheme, regardless of how brief or infrequent the working activity is $^{37}$. As far as the case of independent contractors carrying out sporadic services is concerned, the legal criterion is much more unclear. In principle, they are to be excluded from the scope of Social Security since at least one of the legal requirements is missing: that the activity is performed in a regular manner (de forma habitual) ${ }^{38}$. The problem is how to interpret this ambiguous situation.

Case-law tries to give an answer pointing at a minimum level of (net) income, equivalent to the national minimum wage ${ }^{39}$ (707 euro per month in 2017). Scholars concede that such a rule is not fully adequate $^{40}$, because it is still uncertain and entails a serious risk of fraud as undeclared work. But the solution is even more unsatisfactory when it is projected onto activities based on work-on-demand via apps. On the one hand, it could be easier to measure working time as a way of proving a regular performance. Especially when we take into account, on the other, that it is (could be) common that earnings do not reach a certain minimum amount given the intermittence of the activity. Note that the consequence is to exclude the 'collaborator' from the Social Security system.

The next question deals with how registration and subsequent Social Security contributions (or the lack of both) affect the adequacy of future social benefits. It is not exaggerating to state that there is a serious risk of partial or total lack of protection due to three main factors. One is that the relatively common pattern of sporadic services leads to the absence of compulsory payment of contributions making it impossible to have access the contributory benefits of the Social Security system. Likewise, an additional factor is that protection against employment risks is not fully provided for self-employed since it works on a voluntary basis. And finally, low-level contributions are (potentially) common given the reduced working time and characteristic intermittence, in particularly when it comes to self-employed; again, the benefit amount will feel the negative effects.

In relation to this last factor of downsizing protection, it is important to note that recent legal reforms have aggravated the potential problem in the pension field by increasing the proportionality of benefits with respect to previous contributions (an extension of the period of reference to calculate pensions and a rise in contribution years to draw a full pension). We have to be conscious that this extra effort demanded to the whole working population to keep the current level of pension benefits will be particularly exacting for those professionals rendering services in economic activities based on the use of on-line platforms.

All in all, is the traditional pattern of Social Security coverage inevitably heading towards a reduction of benefits?

It is also important to think over the impact that these new types of businesses could have on a very thorny issue at present in Spain: the financing of Social Security and, by extension, its future sustainability. The premise would be that it is foreseeable that Social Security funds coming from contributions will decrease as a result of the described low (or lack of) contributions associated with the new forms of platform work. Some difficulties arise.

To begin with, the fall of contributory resources is always problematic for Bismarckian-type Social Security systems due to their structural dependence on contributions as the main source of financ-

\footnotetext{
${ }^{37}$ Formally there is a provision that attributes to the Government the ability to exclude from the scope of application of Social Security marginal activities that do not provide for sufficient means to make a living (see section 7.5 of the Social Security General Act).

${ }^{38}$ According to section 305 of the Social Security General Act, those who habitually, personally and directly performs a profit-driven activity, without an employment contract must register with the Special Regime for Self-Employed Workers.

${ }^{39}$ See the Supreme Court Rulings of 29 October 1997 (No. 406/1997) and 20 March 2007 (No. 5006/2005).

${ }^{40}$ DESDENTADO BONETE and TEJERINA ALONSO (2004, 61-67).
} 
ing. That is particularly problematic in the Spanish case where over $90 \%$ of Social Security benefits are paid from employers' and workers' contributions.

On top of it, this threat of imbalance between contributions and benefits becomes more serious if we take into account two circumstances. One, the current financial condition of Social Security (in a critical situation in Spain since 2012). Two, the challenging future linked to the ageing process in the coming years and the subsequent needs of additional resources.

So, we draw the conclusion that, to a certain extent, these new forms of work could undermine the pillars upon which traditional Bismarckian systems have been built. On the one hand, the dependence on the labour market now gives way to a new allocation of (economic) risks led by individualization enhancing a tendency towards social polarization. On the other, Social Security systems face increasing needs of income, caused by growing numbers of pensioners, with a decreasing amount of contributions.

Having said that, and focusing again on Spain, it is pertinent to pose the question whether we should reform our Social Security system in order to face the consequences of the platform economy and new forms of work. In brief, a new design of financing resources seems necessary so that the State assumes a greater role to make up for the foreseeable lack of contributions. To attain this goal, we may think of two different paths. One would represent a first step towards a more Beveridgean system by assuming a significant reduction of benefits and focusing, instead, on reducing poverty through assistance benefits. The other would try to modernize the Bismarckian system: keeping its traditional pattern by reinforcing solidarity mechanisms to compensate for labour precariousness.

\section{Concluding remarks}

Throughout this article we have examined the most relevant legal issues regarding the (slowly) ongoing development of the imprecisely named 'sharing economy' in Spain. In particular, attention has been drawn to the impact that these new types of activities have on the design and effectiveness of labour and social security regulation. This analysis shows what lies behind this emerging economic reality: the 'sharing' economy is a major challenge for two basic institutions of the Welfare State: the labour market and Social Security. So when we are to think of possible legal changes demanded by this new phenomenon, we have to be conscious that it is this Social State itself, and its implications in terms of economic progress and welfare, which is at stake.

\section{Bibliography}

Agut García, C., NúÑez González, C. "The Regulation of Economically Dependent Self-employed Work in Spain: A Critical Analysis and a Comparison with Italy", E-Journal of International and Comparative Labour Studies, Volume 1, No. 1-2, March-June 2012.

Alorsi, A. (2016) "Commoditized workers: case study research on labour law issues arising from a set of 'on-demand/gig economy' platforms", Comparative labor law and policy journal, vol. 37, $\mathrm{n}^{\circ} 3$.

Autor, D. (2014) "Polanyi's Paradox and the Shape of Employment Growth", National Bureau of Economic Research, Working Paper No. 20485.

Cavas Martínez, F. (2017) "Las prestaciones de servicios a través de las plataformas informáticas de consume colaborativo: un nuevo desafío para el Derecho del Trabajo", Revista de Trabajo y Seguridad Social-CEF, No. 406.

CRUZ Villalón, J. (1999) "El proceso evolutivo de delimitación del trabajo subordinado", en: AA.VV. Trabajo subordinado y trabajo autónomo en la delimitación de fronteras de derecho del trabajo: estudios en homenaje al profesor José Cabrera Bazán, Tecnos, Madrid, 1999, pp. 169-192

DAGNino, E. (2015) ““'Uber law: perspectiva jurídico-laboral de la sharing/on-demand economy”, $R e$ vista Internacional y Comparada de Relaciones Laborales y Derecho del Empleo, Vol. 3, No. 3.

DAVIDov, D. (2002) ["The three axes of employment relationships: A characterization of workers in need of protection”, University of Toronto Law Journal, 52 (2002). 
De Groen - Maselli (2016), "The impact of the collaborative economy on the labour market", CEPS Special Report.

De Stefano, V. (2016) "The rise of the «just-in-time workforce»: On-demand work, crowdwork and labour protection in the «gig-economy»", Conditions of Work and Employment Series, No. 71, ILO.

Desdentado Bonete, A., Tejerina Alonso, J.I. (2004), La Seguridad Social de los trabajadores autónomos, Lex Nova, Valladolid.

Drahokoupil, J., Fabo, B. "The platform economy and the disruption of the employment relationship", ETUI Policy Brief, No. 5.

European Commission (206) Communication from the Commission to the European Parliament, the Council, the European Economic and Social Committee and the Committee and the Committee of the Regions, "A European agenda for the collaborative economy", Brussels, 2.6.2016, $\operatorname{COM}(2016) 356$ final.

Ginés I Fabrellas, A., Galvez Duran, S. (2016) "Sharing economy vs. uber economy y las fronteras del Derecho del Trabajo: la (des)protección de los trabajadores en el nuevo entorno digital”, InDretRevista para el análisis del Derecho, No.1.

Mercader Uguina, J. (2017) El futuro del trabajo en la era de la digitalización y la robótica, Tirant lo Blanch, Valencia.

PéRez Rey, J. (2014) El régimen profesional del trabajo autónomo económicamente dependiente: novedades legales y jurisprudenciales, Bomarzo, Albacete.

Prassl, J., RisaK, M. (2016) "Uber, Taskrabbit, and co.: Platforms as employers? Rethinking the legal analysis of crowdwork", Comparative Labour Law and Policy Journal, Vol. 37, Issue 3.

RISAK, M., WARTER, J. (2015) "Legal strategies towards fair conditions in the virtual sweatshop", Paper presented at the IV Regulating for Decent Work Conference (ILO, Geneva, 8-10 July 2015), available at http://www.rdw2015.org/download.

Schwaв (2016) The Fourth Industrial Revolution, World Economic Forum.

Sierra Benítez, M. (2015) "El tránsito de la dependencia industrial a la dependencia digital: ¿qué Derecho del Trabajo dependiente debemos construir para el siglo XXI?", Revista Internacional y Comparada de Relaciones Laborales y Derecho del Empleo, Vol. 3, No. 4, p. 93-118.

SuÁrez Corujo, B. (2014) "Crisis and labour market in Spain”, European Labour Law Journal, Volume 5 (2014), No. 1.

Standing, G. (2014) The precariatat. The new dangerous class, Blommsbury, London, 2014

Todoli Signes, A. (2015) "The end of the subordinate worker: Sharing economy, on-demand economy, Crowdsourcing, Uber economy and other ways of outsourcing", (https://papers.ssrn.com/sol3/ papers.cfm?abstract id $=2719772$ ), p. 17

Todolí Signes, A. (2017) El trabajo en la era de la economía colaborativa, Tirant lo Blanch, Valencia. 